\title{
Making a Difference? \\ Public Perceptions of Coalition, Single-Party, and Minority Governments
}

\author{
Jack Vowles \\ University of Exeter \\ j.vowles@exeter.ac.uk
}

It is usually assumed that coalition governments are less accountable to voters than single-party governments, for various reasons. From this it follows, all other things equal, that public perceptions that governments should make a difference will be lower under coalition, and higher under single-party governments. Minority governments also ought to be less accountable, and thus perceptions of their making a difference in mass publics should also be lower than under majority governments. Using data from modules 1 and 2 of the Comparative Study of Electoral systems, this paper tests these hypotheses.

Paper for presentation at the Canadian Political Science Association Annual Conference, Vancouver, BC, June 4-6 2008. An earlier version of this paper was presented at a Workshop organised by Jeff Karp and funded by the British Academy, 'Voters, Coalitions, and Democratic Accountability' University of Exeter, October 5-6 2007. 


\section{Making a Difference? Public Perceptions of Coalition, Single-Party, and Minority Governments}

One of the main thrusts in the ongoing debate between proponents of alternative electoral systems focuses on coalition governments and, by implication if not direct inference, minority governments as well. Compared to single-party majority governments, coalition or minority governments limit direct accountability between citizens and government and are therefore 'less democratic'. There are at least three reasons for this (Farrell 2001, 196-198).

First, when considering coalition governments compared to single-party governments, their composition cannot be anticipated, as parties will not always signal their coalition intentions before an election (Pinto-Duschinsky 1999; Katz 1997 165-167). Second, as they are more broadly-based, coalitions will be less likely to shift policies as one government is succeeded by another, particularly if change is on the basis of circulation rather than dismissal. If so, there will be less policy difference to be the substance of accountability (Finer 1975; Lijphart 1999). Thirdly, political party 'A' can escape attribution of responsibility for policies or performance by blaming its coalition partners, parties ' $\mathrm{B}$ ', ' $\mathrm{C}$ ', as so on, for not delivering what party ' $A$ ' promised (Gallager, Laver and Mair 2000, 383). Under minority governments, by implication at least two of these factors also apply, albeit slightly differently: policy innovation will be less likely than under majority government, the keeping of policy commitments will be more problematic, and a similar escape from attribution of responsibility that applies to coalitions should follow from minority governments' reliance on parties outside government to pass legislation. If minority governments fail in 'delivery', it is someone else's fault.

Empirical research testing these propositions has tended to sustain them in broad outline, although not necessarily as consistently and as clearly as some might have expected (for example, Katz 1997). Some coalitions are announced in advance, and clear policy alternation between coalitions based on relatively stable party 'blocs' can take place. While in countries most accustomed to coalition governments, power can circulate rather than alternate between parties, but such circulation can be both substantial and effective. And coalition governments can be thrown out wholly if enough electors consider them 'rascals' and elites are sufficiently constrained or at least chastened (Farrell 2001, 196-198; Vowles 1999). Meanwhile minority governments can form stable relationships with outside 'support parties' within the same party system 'bloc', and deliver much of what they promised. And, not the least, claims made about the superior accountability of single-party majority governments are often founded in an ideal-typical construction of their performances that is not always matched when tested empirically, leading to pressure for electoral reform toward proportional representation (Blais 2008).

Leaving these ongoing debates among political elites and political analysts in the background, this paper tests a related proposition. What do members of the mass public make of these matters, if anything? And more particularly, there is a need to focus the discussion away from concentration on the merits and demerits of electoral systems, important as they are, towards types of government. Coalitions and minority governments are not entirely confined to countries with systems of proportional representation, and there is still little if any research that contrasts public perceptions under types of government. Instead, there has been a tendency to subsume coalition and minority governments into the 'proportional' or 'consensus' model of democracy (Powell 2000; Lijphart 1999). While such broad 
constructions have their own value, there has nonetheless been no little or attempt made to partial out the specific effects of coalitions and minority governments.

Drawing on data generated by the Comparative Study of Electoral Systems (CSES), there are been a recent flood of research that inquires into the perceptions and behaviour of mass publics under different electoral systems (for example, Norris 2004, McAllister 2005; Farrell and McAllister 2006; Blais and Bodet 2006; Curtice, forthcoming; Holmberg forthcoming). Some of this develops inferences about coalition, minority, and single party governments and their permutations and interactions (for example, Brockington 2004; Kedar 2005a, 2005b, 2006). But there is much more to explore, particularly given the rich range of hypotheses about voters and coalitions advanced by Downs half a century ago $(1957,142-$ 163).

Do mass publics know, or care about the types of government they experience?

Scattered evidence suggests that many of them do not (for example, Vowles and Aimer 2004, 193-194). General perceptions of political accountability and responsiveness are regularly sought and estimated in a host of sample surveys, and these tend to indicate, with few exceptions, that increasing numbers of members of the mass public are sceptical about the ability of their political leaders to listen to their electorates. From scepticism about politicians many citizens may move into outright cynicism, and their disillusion is subject to alternate interpretations. Some regard greater public disaffection as a consequence of higher levels of information provided by a mass media less deferential and supportive of politicians than in the past, higher levels of education, and thus a more sophisticated and realistic society made up of 'critical citizens' (for example, Norris, 1999; Dalton 2002). Others see the trend as subversive of democratic norms and commitment, encouraged by a mass media too prone to focus on personalities rather than substantive debate, not generating information of sufficient depth and richness and thus reducing 'civic literacy' (for example, Milner 2002). They point to declining levels of 'conventional' political participation not necessarily replaced by increases in new forms of participation that do not necessarily mobilise citizens consistently or effectively.

Milner (2002) makes a case that such trends are weaker in countries with proportional representation - once more, a focus on electoral institutions. But many of the claims made for 'consensus democracy' apply to the nature of more broadly-based decision-making processes that are more directly related to the existence of coalition and minority governments, and only indirectly to the electoral system that may - or sometimes may not - underpin those types of government. Some recent research in this vein, moreover, has partialed out the effects of 'broad coalitions' on political efficacy and found negative effects. However, this remains in the context of negative findings for disproportionality, as well (Karp and Banducci 2008). It is an intriguing paradox increasingly brought to our attention that while proportional representation may indeed enhance efficacy, one of its major consequences, coalition government, probably does not. But what then of minority government, the alternative solution to problems of government formation in the fragmented party systems that are encouraged - but again by no means determined - by proportional representation? The theory hypothesises there should be a similarly negative effect on perceptions. But if so, why does proportional representation maintain its positive effects?

In the field since 1996, the CSES contains data from over 40 countries and 70 elections, made up of two modules, both of which share key dependent variables. Political efficacy, referred to above, is estimated by responses to a five-point scale based on 'Some 
people say that no matter who people vote for, it won't make a (any) any difference to what happens. Others say that who people vote for can make a (big) difference to what happens'. A question more amenable to perceptions of the potential for policy differences between governments, and thus the potential for the attribution of responsibility, is 'Some people say that no matter who people vote for, it won't make a (any) difference to what happens. Others say that who people vote for can make a (big) difference to what happens'. A complication in the interpretation of these questions is variation in their form between the addition or absence of 'big/any'. However, the effect of this difference is easily estimated (Vowles 2008). 'Who is in power makes a difference' is therefore the dependent variable investigated here. Data currently available that contains the relevant variables from the CSES covers 38 countries and 70 elections. The countries and elections are listed in the Appendix.

As a dataset, the CSES has strengths and weaknesses. It is a source - in many cases the only source - of data at the individual level, taken post-election, pertaining to issues of electoral accountability and responsibility. That analysed here contains data from 38 countries over ten years, some countries sampled up to three times. Problems exist, however, and need to be given recognition. At the macro-level, the countries are not randomly selected, and therefore constitute neither a sample nor a universe. It can be argued that the countries represented do provide a range of variation that reflects that in the wider universe, more or less. Nonetheless, the distribution of that variation is not necessarily representative of all possible cases and, indeed, is unlikely to be so. While the data is of great value, nonetheless, it has to be used carefully.

The primary hypotheses of this paper have been sketched out, but need explicit definition as follows. The data from which the various independent variables are drawn falls, of course, into two categories, macro-level and micro-level, the most central being at the macro-level, hypotheses 1 and 2 .

1. The larger the number of parties in government, the less likely that members of the mass public will perceive that 'who is in power makes a (big) difference'. The government is best defined as that in office immediately prior to the election in question.

2. Under minority government prior to the election, members of the mass public will be less likely to perceive that that 'who is in power makes a (big) difference' and, under majority government, the opposite will apply.

Such hypotheses are advanced, of course, on the usual basis of 'all other things equal'. The following list of secondary hypotheses therefore covers what one should expect from the control variables one can explicitly or implicitly derive from the framework outlined above in combination with findings from the relevant literature.

3. If public perceptions of democratic accountability are in secular decline, we might expect the passage of time to have a negative effect of perceptions that who is in power makes a difference. The year of the election from which data was collected therefore becomes an appropriate control variable.

4. Party system fragmentation at the legislative or parliamentary level sets the scene for either coalition or minority government, but does not determine either outcome and thus is a necessary control in the form of an index of effective parliamentary parties (for more detail see Appendix). This index is usually logged to capture the levellingoff effect of fragmentation as the number of parties increases. 
5. Similarly, whether the electoral system is proportional or majoritarian forms a similar backdrop. Once more, details of operationalisation can be found in the Appendix, although it should be noted that semi-proportional systems take an intermediate position on a scale that is shaped by a combination of district magnitude and effective threshold.

6. The nature of the dependent variable, notably its personalised format of 'who' is in power, makes it highly likely that members of mass publics in Presidential systems are more likely to agree that 'who is in power makes a difference'. Further, they will be more likely to agree where Presidential power is high, and somewhat less likely when it is lower. For this variable, the Shugart-Carey index of Presidential power is brought to bear, with parliamentary systems scoring 0 (again, see the Appendix for further details).

7. Another reasonable expectation is that the greater the role of government in the economy, the more likely members of the mass public will consider that who is in power makes a difference, making an estimate of government expenditure over GDP an appropriate control.

8. A further relevant control is the historical extent of democracy in the various countries contained in the dataset, over the life experience of the majority of the respondents: in short, distinction between continuous democracies and those that have become democratic more recently. To take account of the full variation within the experiences of new and old democracies, this is expressed by an average of the Freedom House index for each country/election case since its first appearance in 1973.

The remaining control variables are micro-level and indicate, across various dimensions, the extent to which respondents within each nested country/election case vary in their predispositions to perceive democratic accountability.

9. One assumes that people expressing party preferences, and the strength of those preference, will make them more likely to perceive that who is in power makes a difference than those with no or weaker preferences. Following Karp and Banducci (2008), this variable is constituted from like/dislike scales for the various parties in each country (see Appendix).

10. Over and above party preferences, one would expect to see people who voted for the parties in government after the election to perceive difference, as compared to those who did not vote or who voted for parties that remained out of office. We might expect, however, an even stronger perception of difference from those who voted for parties in government before the election that failed to regain office afterward. This measure also has the effect of estimating at the micro-level the effects of government change, an additional potential source of perceptions of difference.

11. Finally, education is likely to effect perceptions that power makes a difference. One infers that the effect should be positive, unless alternative political elites have converged in their policies and behaviour so much that the most politically-informed persons will tend to reflect that situation in their perceptions, while those lessinformed could continue to perceive differences. This variable is estimated by a simple dummy variable for university degree. 
Preliminary investigation of the structure of the data and the relationships between some of the key independent variables now follows. Of particular interest are the distributions of coalition/non-coalition and minority/majority governments across electoral systems and the newer and older democracies.

Table 1: Independent Variables Across Electoral Systems and Newer and Older Democracies

\begin{tabular}{|c|c|c|c|c|c|c|c|c|c|}
\hline Means & $\begin{array}{r}\text { No, govt. } \\
\text { parties }\end{array}$ & $\begin{array}{r}\text { Min- } \\
\text { Maj }\end{array}$ & $\begin{array}{r}\text { Eff, Parl. } \\
\text { Parties }\end{array}$ & $\begin{array}{r}\text { Govt/ } \\
\text { GDP }\end{array}$ & Dem. & $\begin{array}{l}\text { Pres. } \\
\text { Power }\end{array}$ & Win & Lose & $\begin{array}{l}\text { Party } \\
\text { Pref. }\end{array}$ \\
\hline \multicolumn{10}{|c|}{ Democracy } \\
\hline Newer & 2.24 & 0.53 & 3.93 & 19.94 & 0.37 & 7.32 & 0.27 & 0.09 & 6.76 \\
\hline Older & 2.42 & 0.31 & 3.77 & 17.80 & 0.96 & 2.17 & 0.32 & 0.08 & 6.70 \\
\hline \multicolumn{10}{|l|}{ System } \\
\hline PR & 2.59 & 0.43 & 4.51 & 20.13 & 0.73 & 3.27 & 0.32 & 0.10 & 6.96 \\
\hline Majority & 1.93 & 0.27 & 3.07 & 14.56 & 0.75 & 6.47 & 0.29 & 0.06 & 6.29 \\
\hline Semi-PR & 2.11 & 0.50 & 3.14 & 19.75 & 0.50 & 6.06 & 0.26 & 0.08 & 6.64 \\
\hline
\end{tabular}

NOTES:

Democracy Newer and Older: Based on a 50:50 split of the country/election cases, thus the 35 most low ranked democracies and the 35 higher ranked democracies.

System: PR=1-.51, Majority 0-.49, Semi-PR .5.

No. govt parties: absolute number of parties in government before election

Min-Maj: Minority=1, Majority- 0

Eff. Parl. Parties: Effective Number of Parliamentary Parties

Democracy: Average Freedom House index 1973-election (High Democracy=1 - Low=0)

Pres. Power: The Shugart-Carey index of Presidential Power, $0=$ No elected President, up to a maximum of 17 in this dataset.

Win: Voted for Party in government after the election $=1$, Others $=0$

Lose: Voted for party losing office after the election $=1$, Others $=0$

Party Preference: Respondent's level of preference for their highest scoring party (10-0).

Coalitions are almost equally common in the 'newer' and 'older' democracies, with a slight edge to the old. There are 10 country/election cases in the dataset that are fully majoritarian ( 5 countries), and five that are more majoritarian than proportional (3 countries). Australia, France, and the Philippines are responsible for an average of almost two-party coalitions in the majoritarian cases. Minority governments are clearly more popular in the older democracies, and in the PR and semi-PR cases. Nonetheless, there were some minority governments in majoritarian countries: the United States in 1996, with government divided between a Democratic President and Republican Congress, the Philippines in 2004, and before the two Korean elections. Majoritarian electoral systems were unsuccessful in bringing about effective two-party systems in all situations registered in this data, the average being a three-party system. Nonetheless, parliamentary party fragmentation was considerably higher in the PR cases, as one would expect. The importance of government in the economy was only slightly higher in the older democracies, but considerably higher under PR than in the majoritarian and semi-PR cases. The average old democracy was very close to a full rating: it is worth noting that the average for new democracies is far more shaped by their their histories rather than their more current Freedom House scores. The lower average for 
democratic history in the semi-PR category similarly reflects choices made by those setting up many new democracies to adopt non-compensatory mixed electoral systems, the main grouping in this category. The newer democracies in the dataset have also been more likely to adopt Presidential than parliamentary systems, and the former are also more popular in majoritarian and semi-proportional systems. The proportion of 'winners' is slightly higher in PR systems, indicating their governments are more broadly-based, coalitions being the main explanation. However, there are almost twice as many 'losers' in PR systems, indicating movement out of office is more common - at least in this selection of countries and elections - than might be expected given claims that government change is less prevalent under PR and thus 'rascals' are more likely to stay in office. Finally, party preferences appear as strong in newer as in older democracies, and slightly higher under PR, consistent with other evidence (Karp and Banducci 2008, Bowler, Lanoue, and Savoie 1994).

\section{Table 2: Partial Correlations (Controlling for Big/Any) Between 'Who is in Power Makes a Difference' and Key Independent Variables}

\begin{tabular}{|c|c|c|c|c|c|}
\hline $\begin{array}{r}\text { Minority Govt, } \\
0.01\end{array}$ & $\begin{array}{r}\text { Parties in Govt. } \\
0.03\end{array}$ & $\begin{array}{r}\text { PR } \\
0.11\end{array}$ & $\begin{array}{l}\text { Year } \\
-0.07\end{array}$ & $\begin{array}{r}\text { Govt/ } \\
\text { Economy } \\
0.13\end{array}$ & $\begin{array}{r}\text { Pres. Power } \\
0.30\end{array}$ \\
\hline $\begin{array}{r}\text { Winner } \\
0.11\end{array}$ & $\begin{array}{r}\text { Loser } \\
0.06\end{array}$ & $\begin{array}{r}\text { University } \\
0.05\end{array}$ & $\begin{array}{r}\text { Party Pref. } \\
0.16\end{array}$ & $\begin{array}{r}\text { Log. Eff. } \\
\text { Parties } \\
0.07\end{array}$ & $\begin{array}{r}\text { Democracy } \\
-0.06\end{array}$ \\
\hline
\end{tabular}

Table 2 maps out partial correlations between the dependent and independent variables, controlling for the shift in question format. No significance levels are reported as the number of individual-level cases is very high. This means that all individual-level relationships are significant and no robust estimation of standard errors was possible in the available statistical procedure to take into account the clustering of micro-cases within the country/election macro-cases. However, this information is primarily to demonstrate the zero-order correlations before moving on to multivariate analysis. On the surface, the relationships between 'who is in power' and the two key government-type variables are not promising. Both are positive, the wrong direction, but are so small as to be without much meaning. PR has a positive effect of a greater magnitude, also unexpected. The negative effect for passage of time. 'year' is in the expected direction. Party system fragmentation is associated with higher perceptions of difference, again unexpected, and new democracies are associated with less perceptions of difference.

Table 3 reports findings from an ordinal logit model that regresses these independent variables against 'who is in power', with robust standard errors adjusted for clustering. Probability change effects have been estimated for each category of the dependent variable for each independent variable where there is a statistically significant relationship. For example, the effect of being asked the 'big/any' version of the question is such that a person perceiving the maximum power effect is nearly 7 per cent less likely to have been asked the 'big/any' version. (The probability estimates across each 'who is in power' category, it can be noted, sum to zero, with positive effects at one end of the range offset by negative effects at the other). 


\section{TABLE 3 ABOUT HERE}

One substantive finding does stand out. Persons in a country where the government in power before the election was of minority status were just over 4 per cent less likely to be in the 'most difference' category, and correspondingly more likely to be in the lesser difference categories. An alternate version of the model showed no effects for number of parties in government. However, a variety of interaction effects were tested. The only significant finding of substantive interest was between democratic history and the number of parties in a coalition. In the newest possible democracy, represented by the main effect indicated in table 3 , the number of government parties prior to the election in question had no significant effects. (With democracy at 0 , this scenario would be one representing the first election in a transition to democracy and, consequently, somewhat theoretical, as no cases in the dataset represent this possibility). However, the older the democracy, the more negative effects on perceptions of making a difference, so much so that a person in the oldest and most consistent democracy with a maximum number of coalition parties is nearly 28 per cent less likely to be in the category for those perceiving the maximum amount of difference between 'who is in power'. One should note, however, that this is also somewhat theoretical, as no older democracy in the dataset had a coalition government of that size (ten parties, found in Lithuania before its election in 1997. Figure 1 indicates the shape of the relationship more clearly, indicating a 20 per cent drop in the probability of choosing the 'most difference' category between a person in a country having had a five-party as compared to a one-party government, all other variables held constant. The difference between a one-party and twoparty coalition is therefore only 4-5 per cent.

Figure 1: Probability Changes in Perceiving Most Difference in Who is in Power from a One-Party to a Five-Party Government in the Oldest and the Newest Democracies

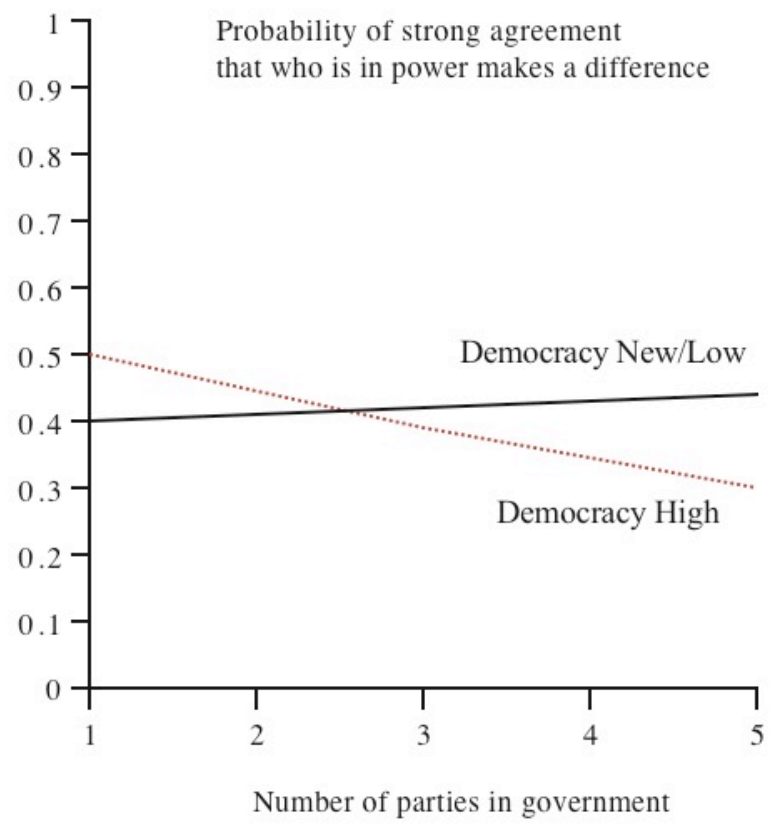


For the most part the various control variables have the expected effects: for example, government's role in the economy, presidential power, strength of party preference, winners and losers (with losers, as anticipated, having the bigger impact). University education has positive effects on perceptions of who is in power making a difference. Testing the possibility that this relationship might reverse in older democracies, an interaction found no significant difference. One could infer, on this basis, that perceptions of no difference are mainly those of the less informed. Analysis of political knowledge across the dataset is, unfortunately, limited by the inconsistency of questions asked across different countries and a high number of missing values.

Given the findings on government type, the continued positive relationship between $\mathrm{PR}$ and 'who is in power makes a difference' is worth further reflection. The sign of the estimate for the log of effective parliamentary parties is also positive, but non-significant. Both these factors that enhance the probability of coalitions and minority governments offset their negative effects. For example, all other things equal, a person having experienced a three-party coalition under PR and another having experienced a one party majoritarian government should be likely to generate much the same distribution of responses. Similarly, the model indicates that a person experiencing a single-party minority government under PR should still be about five per cent more likely to choose the most difference category than a person having experienced a one-party majority government in a majoritarian system.

Why should PR enhance perceptions that alternative governments can 'make a difference to what happens'? Regardless of the composition of particular governments, PR could generate a greater sense that governments are closer to the median voter, as Powell has shown (Powell 2000). This means that a larger majority of voters will feel that government is responsive to their concerns. However, Blais and Bodet (2006) use CSES data to refute this analysis using more recent CSES data. Perhaps respondents construct the question as meaning making a difference to them by way of reflecting their concerns. At least in this dataset, circulation out of government is stronger under PR. Perhaps there are perceptions of fairness and legitimacy that dispose people under PR to express more confidence in government responsiveness. Further analysis of CSES data is needed to address these puzzles in more depth.

The most obvious conclusion from this analysis returns the discussion to a constant refrain in debates about electoral systems: the question of trade-offs, and how they can be traded. Political actors in democratic societies face combinations of constraints and choices. In old democracies they are more constrained, in new democracies less so. Systemreinforcing constraints lie in historic cleavage structures, and the interests of entrenched elites. Electoral systems in old democracies are generally 'givens', although less so than in the past. Choices of government types are constrained by voters within systems, and elites negotiate what choices are provided for them. In most countries, one government type dominates. Within coalition-based systems, the number of government actors may of course vary. Citizens agree with elites that smaller coalitions are more likely to 'make a difference'. In terms of public confidence in 'delivery', in the oldest democracies, where elites have a choice excluding a single party majority government, a minority single party government and a two-party majority coalition bear about the same cost in terms of lower public perceptions of potential 'difference'. But if the cost of a majority is a three-party coalition, the evidence presented here suggests that a minority government could generate higher public confidence: at least, that is, if 'difference' is what voters want. 


\section{REFERENCES}

Beck, T., Clarke, G., Groff, A., Keefer, P. and Walsh, P. 2001. 'New tools in comparative political economy: the Database of Political Institutions' World Bank Economic Review 15:1, 165-176.

Blais, Andre, ed., 2008, To Keep or to Change First Past the Post: The Politics of Electoral Reform. Oxford, Oxford University Press.

Blais, André, and Marc André Bodet. 2006. 'Does Proportional Representation Foster Closer Congruence Between Citizens and Policy Makers?' Comparative Political Studies 39, 10, 1243-62.

Bowler, Shaun David Lanoue and Paul Savoie, 'Electoral Systems, Party Competition, and Strength of Partisan Attachment: Evidence From Three Countries', Journal of Politics $56,991-1007$.

Brockington, David. 2004. 'The Paradox of Proportional Representation: The Effect of Party Systems and Coalitions on Individuals' Electoral Participation', Political Studies 52, 3, 469-90.

Comparative Study of Electoral Systems, 2003. Comparative Study of Electoral Systems 1996-2001, Module 1 Micro-District-Macro Data. Ann Arbor, University of Michigan, Center for Political Studies.

Comparative Study of Electoral Systems, 2005. Comparative Study of Electoral Systems 2001-2006, Module 2 Third Advance Release. Ann Arbor, University of Michigan, Center for Political Studies.

Curtice, John. Forthcoming, 'Who Represents Us Best: One Member or Many?' In $A$ Comparative Study of Electoral Systems 1995-2000. Ed. Hans-Dieter Klingemann. Oxford, Oxford University Press.

Dalton, R., 2004. Democratic Challenges, Democratic Choices: the Erosion of Political Support in Advanced Industrial Democracies. Oxford, Oxford University Press.

Downs, A., 1957, An Economic Theory of Democracy. New York, Harper.

Farrell, David M., 2001. Electoral Systems: A Comparative Introduction. Palgrave, Basingstoke.

Farrell, David M., and Ian McAllister. 2006. 'Voter Satisfaction and Electoral Systems: Does preferential voting in candidate-centred systems make a difference?' European Journal of Political Research 45, 5, 723-49.

Finer, S.E., ed., 1975. Adversary Politics and Electoral Reform. London, Anthony Wigram.

Gallagher, M., Laver, M., and Mair, P., 2000. Representative Government in Modern Europe. New York, McGraw Hill.

Heston, A., Summers, R. and Aten, B. 2006. Penn World Table Version 6.2, Center for International Comparisons of Production, Income and Prices at the University of Pennsylvania, September.

Holmberg, Sören. Forthcoming, 'Candidate Recognition in Different Electoral Systems'. In $A$ Comparative Study of Electoral Systems 1995-2000. Ed. Hans-Dieter Klingemann. Oxford, Oxford University Press.

Karp, Jeffrey A. and Susan Banducci, 2008. 'Political Efficacy and Participation in TwentySeven Democracies: How Electoral Systems Shape Political Behaviour', British Journal of Political Science 38, 311-334,

Katz, Richard S., 1997. Democracy and Elections. Oxford, Oxford University Press. 
Kedar, Orit. 2005a. 'How Diffusion of Power in Parliaments Affects Voter Choice'. Political Analysis 13, 4, 410-429.

Kedar, Orit. 2005c. 'When Moderate Voters Prefer Extreme Parties: Policy Balancing in Parliamentary Elections'. American Political Science Review 99, 185-99.

Kedar, Orit. 2006. 'How Voters Work around Institutions: Policy Balancing in Staggered Elections'. Electoral Studies. 25, 3, 509-527.

Lijphart, A., 1999. Patterns of Democracy. New Haven: Yale University Press.

McAllister, Ian. 2005. 'Accountability, Representation and Satisfaction with Democracy'. International Journal of Public Opinion Research 17, no. 3, 371-79.

Milner, Henry, 2002, Civic Literacy. How Informed Citizens Make Democracy Work. Hanover, University Press of New England,

Norris, Pippa, ed., 1999. Critical Citizens: Global Support for Democratic Governance. Oxford, Oxford University Press.

Norris, Pippa, 2004. Electoral Engineering: Voting Rules and Political Behaviour. Cambridge, Cambridge University Press.

Pennings, P., 2000 'Parliamentary Control of the Executive in 47 Democracies'. Paper presented at the Workshop 'Parliamentary Control of the Executive', $28^{\text {th }}$ Joint Sessions of Workshops of the European consortium for Political research, 14-19 April.

Powell, G.B., 2000. Elections as Instruments of Democracy. New Haven, Yale University Press.

Pinto-Duschinsky, Michael, 1999. 'Send the Rascals Packing: Defects of Proportional Representation and the Virtues of the Westminster Model', Representation 36, 117 26.

Shugart, M., and Carey, J.M, 1992. Presidents and Assemblies: Constitutional Design and Electoral Dynamics. Cambridge, Cambridge University Press..

Vowles, J., 1999. 'Rascals and PR: How Pinto-Duschinsky Stacked the Decks' Representation, 36, 2, 137-142.

Vowles, Jack, 2008. Does globalization affect public perceptions of 'Who in power can make a difference'? Evidence from 40 countries, 1996-2006, Electoral Studies 27, 1, 63-76.

Vowles, Jack, and Peter Aimer, 2004. "Conclusion" in Jack Vowles, Peter Aimer, Susan Banducci, Jeffrey Karp and Raymond Miller, eds., Voters' Veto: the 2002 Election in New Zealand and the Consolidation of Minority Government. Auckland, Auckland University Press. 


\section{Appendix: Acknowledgements and Variable Definitions}

Acknowledgements are due to the work of Dave Howell, Ashley Grosse and Karen Long of the Comparative Study of Electoral Systems, Center for Political Studies, University of Michigan, its Organising Committee, and to the collaborators who collected the data in the various countries. The CSES dataset and full documentation (CSES 2003, 2005) can be downloaded from http://www.umich.edu/ nes/cses/cses.htm.

The full list of 70 country/elections from CSES modules one and two included in this dataset are listed below. Countries missing from the current list of CSES cases either had key missing variables, either the dependent variable 'who is in power', or data making it possible to identify winners and losers, or could not be classified in terms of the types of government.

\section{Variable Definitions and Sources}

$\%$ Government component Share/Real GDP, current year Penn World Tables 6.2 (Heston, Summers and Aten 2006). After 2004, the most recent year available in the dataset.

Proportional representation systems score 1, majoritarian systems score 0 , and mixed or semi-proportional systems score appropriately in between. Where a country shifts from one system to another at the election concerned, the score is averaged between the two systems: for example, New Zealand in 1996 scores 0.5 , because it changed from a pure majoritarian to a fairly pure PR system at that election. Japan in 1996 is scored 0.5. It changed from SNTV to a mixed-member majoritarian (MMM) system in 1996. The effects of SNTV appear to have advantaged one large party but allowed representation from a variety of small parties, and the MMM system appears to have similar effects. Codings for other mixed countries require explanation. Chile is coded at 0.25 because of its unique system of two-member districts and the party coordination within left and right blocs that takes place to preserve a multi-party system. Where MMM systems have a relatively even split between single member districts (SMD) and PR lists, they are coded at 0.5 (Hungary, Lithuania, Mexico, Taiwan, Ukraine). Where the PR component is significantly smaller, they are coded depending on the ratio of seats in each component. For example, Korea scores 0.25 . Spain, although technically with a PR system, does not produce proportional outcomes because of the institutional factor of low district magnitude, and was therefore coded at 0.5 . Switzerland, although normally classified as having a PR system, elects its government by a joint sitting of two Houses that form the Federal Assembly, one of which is elected by two members from each canton, and forms about 20 per cent of the Federal Assembly. Thus Switzerland is scored at 0.8. This formula favours the two traditional large parties, and helped prevent a change in government composition after the 1999 election that would have produced a more representative government.

Legislative party fragmentation is as an average of the legislatures before and after the election in question and estimated using a transformation of the Herfindahl index, from the World Bank's Database of Political Institutions (Beck et al, 2001). This is similar to the denominator of the better-known effective number of parliamentary parties formula, 1 divided by the sum of the squares of the fractional shares of each party's seats. It differs in that except it includes all parties, however small, and counts each independent member as a party. Dividing one by the Herfindahl index produces the effective number of parliamentary parties, subject to the difference noted above. This is then transformed again into its natural $\log$ so as to capture leveling off effects at higher levels of fragmentation. 
Presidentialism and Presidential Power. Presidential systems provide examples of executive government as its most powerful. The more powerful a single directly elected leader, the more likely that citizens might feel who is in power makes a difference, on top of possible 'framing' effects suggested above. Therefore the index of Presidential Power developed by Shugart and Carey $(1992,150)$ is employed here. All countries lacking a directly elected President score $=0$. Others scored according to Shugart and Cary 1992, Pennings 2000, or from CSES macro-data and constitutional documents (Taiwan, Ukraine, and Albania).

'Democracy since 1973' is estimated by a reversed average of the Gastil or Freedom House index over the years since its beginnings in 1973 (http://freedomhouse.org), transformed to run between 1 and 0 . This means that the oldest democratic countries score high, the newest democratic low. Where countries did not exist, as part of larger states, the index scores for those countries are applied for those years.

Winners and losers. Winners are respondents voting for winning parties, defined as those remaining in or entering government after the election. Losers are those who voted for parties that were defeated, or leaving government due to the election.

Strength of Party Preference. The highest score given by each respondent on the party like/dislike scales in the two CSES modules (0-10). In other words, this represents the score given between 0 and 10 to the respondent's most preferred party. 
Country/Election Cases

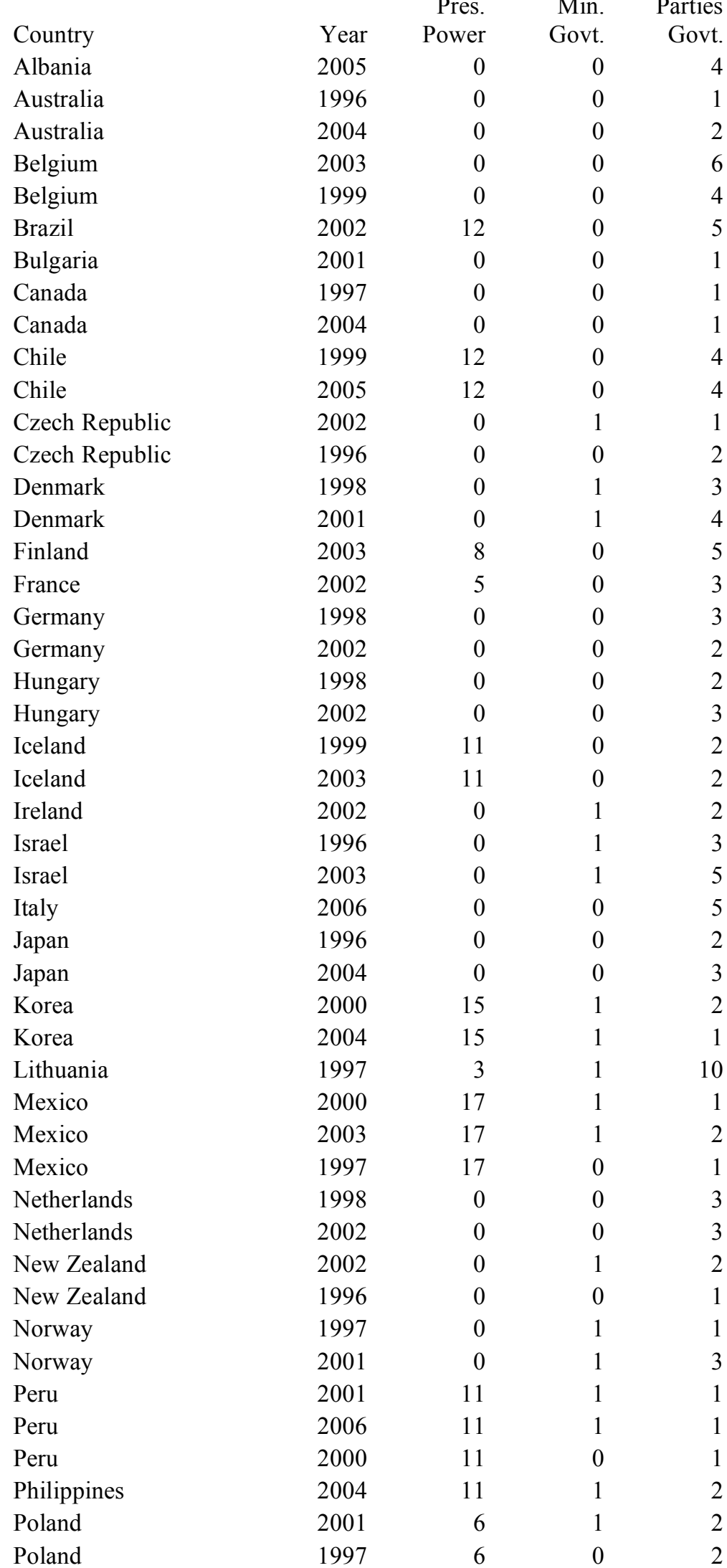




\begin{tabular}{lrrrr} 
Country & Year & $\begin{array}{r}\text { Pres. } \\
\text { Power }\end{array}$ & $\begin{array}{r}\text { Gin. } \\
\text { Povt. }\end{array}$ & Govt. \\
Portugal & 2002 & 8 & 1 & 1 \\
Portugal & 2005 & 8 & 0 & 2 \\
Roumania & 2004 & 4 & 1 & 1 \\
Roumania & 1996 & 4 & 0 & 2 \\
Russia & 1999 & 16 & 1 & 1 \\
Russia & 2004 & 16 & 1 & 1 \\
Slovenia & 1996 & 5 & 0 & 3 \\
Slovenia & 2004 & 5 & 0 & 3 \\
Spain & 1996 & 0 & 1 & 1 \\
Spain & 2000 & 0 & 0 & 1 \\
Spain & 2004 & 0 & 0 & 1 \\
Sweden & 1998 & 0 & 1 & 1 \\
Sweden & 2002 & 0 & 1 & 1 \\
Switzerland & 1999 & 0 & 0 & 4 \\
Switzerland & 2003 & 0 & 0 & 4 \\
Taiwan & 2001 & 3 & 1 & 1 \\
Taiwan & 2004 & 3 & 1 & 1 \\
Taiwan & 1996 & 3 & 0 & 1 \\
Ukraine & 1998 & 14 & 1 & 5 \\
United Kingdom & 1997 & 0 & 0 & 1 \\
United Kingdom & 2005 & 0 & 0 & 1 \\
United States & 1996 & 13 & 1 & 1 \\
United States & 2004 & 14 & 0 & 1 \\
& & & & \\
\hline & & & &
\end{tabular}


Table 3: Who is in Power Makes a Difference: Ordinal Logit Model

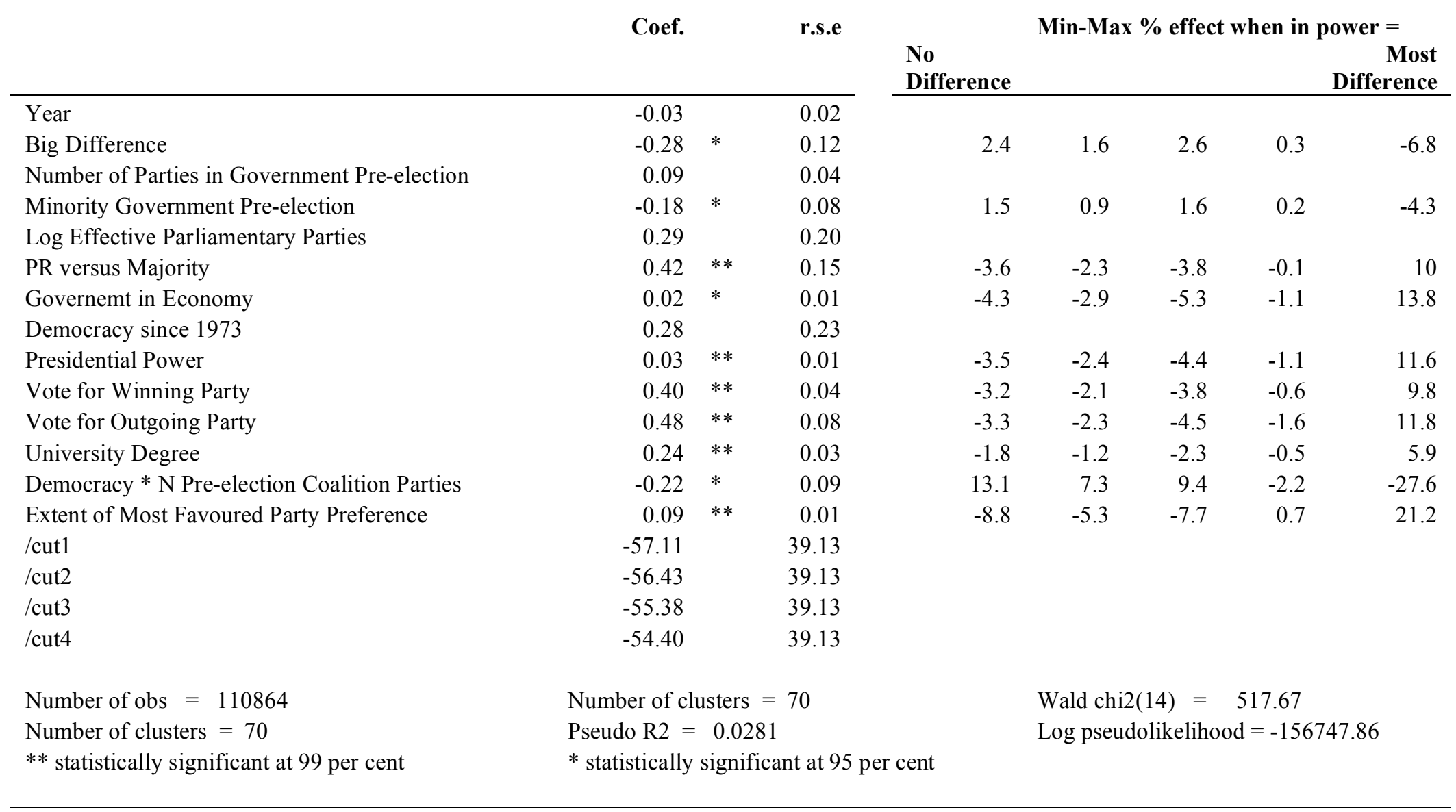

